\title{
An Analysis of Indian Pharmaceutical Sector using ABCD Framework
}

\author{
Sanjana S. Shenoy ${ }^{1} \&$ Shailashri V. T. ${ }^{2}$ \\ ${ }^{1}$ Research Scholar, College of Management and Commerce, Srinivas University, \\ Mangaluru- 575001, India \\ OrcidID: 0000-0002-4415-1084; Email id: sanjanashenoy.cmc@ srinivasuniversity.edu.in \\ ${ }^{2}$ Research Professor, College of Management and Commerce, Srinivas University, \\ Mangaluru- 575001, India \\ OrcidID: 0000-0002-1684-238X; E-mail id: shailashrivt@ gmail.com
}

Area of the Paper: Management.

Type of the Paper: Case Study.

Type of Review: Peer Reviewed as per $|\mathrm{C}| \mathrm{O}|\mathrm{P}| \mathrm{E} \mid$ guidance.

Indexed In: OpenAIRE.

DOI: https://doi.org/10.5281/zenodo.5889767

Google Scholar Citation: IJCSBE

\section{How to Cite this Paper:}

Shenoy, Sanjana S., \& Shailashri, V. T., (2021). An Analysis of Indian Pharmaceutical Sector using ABCD Framework. International Journal of Case Studies in Business, IT, and Education (IJCSBE), 6(1), 1-13. DOI: https://doi.org/10.5281/zenodo.5889767

International Journal of Case Studies in Business, IT and Education (IJCSBE)

A Refereed International Journal of Srinivas University, India.

Crossref DOI : https://doi.org/10.47992/IJCSBE.2581.6942.0145

(C) With Authors.

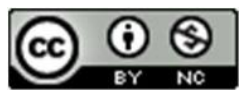

This work is licensed under a Creative Commons Attribution Non-Commercial 4.0 International License subject to proper citation to the publication source of the work.

Disclaimer: The scholarly papers as reviewed and published by the Srinivas Publications (S.P.), India are the views and opinions of their respective authors and are not the views or opinions of the S.P. The S.P. disclaims of any harm or loss caused due to the published content to any party. 


\title{
An Analysis of Indian Pharmaceutical Sector using ABCD Framework
}

\author{
Sanjana S. Shenoy ${ }^{1} \&$ Shailashri V. T. ${ }^{2}$ \\ ${ }^{1}$ Research Scholar, College of Management and Commerce, Srinivas University, \\ Mangaluru- 575001, India \\ OrcidID: 0000-0002-4415-1084; Email id: sanjanashenoy.cmc@ srinivasuniversity.edu.in \\ ${ }^{2}$ Research Professor, College of Management and Commerce, Srinivas University, \\ Mangaluru- 575001, India \\ OrcidID: 0000-0002-1684-238X; E-mail id: shailashrivt@ gmail.com
}

\begin{abstract}
Purpose: The understanding of changing industry dynamics is essential for any business firm that wishes to enter, earn returns and sustain in any given industry. The study/analysis of an industry is essential for various stakeholders. For instance, creditors/investors take decisions concerning investment only after a thorough analysis of the current scenario and prospects of an industry. The ABCD framework is an effective tool of industry analysis for understanding both the positive and negative impact of the industry's operations and the factors that support or hinder the effective functioning of the industry. The Indian Pharmaceutical Industry, known as the pharmacy of the world, is the leading supplier of generic drugs. It's contribution in achieving various public health outcomes such as polio eradication, lower treatment costs, to name a few, are immense. The industry has proved its resilience even in the COVID-19 pandemic era.
\end{abstract}

Design/Methodology/Approach: This paper studies the Indian Pharmaceutical Sector in terms of its Advantages, Benefits, Constraints and Disadvantages. The data for the same is collected through published reports on the Indian Pharmaceutical Sector. Apart from ABCD Framework, other tools of industry analysis such as the Herfindahl-Hirschman index are used in the study.

Findings/Result: The benefits of the pharma industry to the economy as well as to public health outcomes have been many and varied. The industry enjoys many advantages, the main among them being the low cost of manufacturing, which has contributed to its growth. The main disadvantage of the industry is its adverse impact on the ecology. Rigorous regulations are its chief constraints.

Originality/Value: This paper studies the Indian Pharmaceutical industry using the ABCD model, which gives an all-round perspective of the industry.

Paper Type: Research Case Study based on industry analysis.

Keywords: Indian Pharmaceutical Industry, ABCD framework, Generic Drugs, FDA Compliance.

\section{INTRODUCTION :}

An industry, being an open system, is affected by and in turn, affects the environment in which it operates. Industry analysis is a tool that enables the understanding of the various factors that influence a firm in its quest for profits and sustainability. For a firm that wishes to earn profits, grow and consolidate its position in any given industry, industry analysis is inevitable. An understanding of factors such as, the lifecycle stage in which the industry currently finds itself (growth, maturity or decline), the number of competitors and the extent of competitive rivalry prevailing, type of competition (monopoly, oligopoly, imperfect competition), the pace at which technological upgradation occurs in the industry, the extent of investment in $\mathrm{R} \& \mathrm{D}$, the expectation of the stakeholders is essential for a firm to devise strategies to compete in the industry. 
A number of tools are available for industry analysis. Important among them are the Porter's Five Forces theory for Competition Analysis [1] SWOT Analysis, PEST Analysis etc. The ABCD Analysis [2] is one such framework. The ABCD framework when applied to an industry enables industry members to not only to identify the advantages they can derive from the environment within which they operate but also the constraints they must overcome to earn profits and survive in the long run. The framework also enables the evaluation of the impact of the industry's operations on the various stakeholders, in terms of the benefits they derive and the disadvantages they endure. The framework when applied to the pharma industry highlights its advantages, benefits, constraints and disadvantages.

The Indian Pharmaceutical Industry occupies a prominent position in the global pharma scenario. The industry is the largest supplier of generic drugs, world over. It is popularly known as the "Pharmacy of the world." It has many other achievements to its credit such as meeting $50 \%$ of worldwide requirement vaccines, $40 \%$ of generic drug requirement in the US and $25 \%$ of all drugs in the UK [3]. The industry is valued presently at US \$ 41 billion [4].

India ranks $3^{\text {rd }}$ worldwide for pharma production by volume and $14^{\text {th }}$ by value. The Indian Pharmaceutical industry is highly fragmented with around 3000 drug manufacturing companies and 10,500 manufacturing units [5]. The industry comprises domestic as well as international companies. In 2020, domestic companies had 85\% share in the local market and the remaining $15 \%$ market share was held by foreign companies. This is in sharp contrast to the situation in 1969, where domestic companies had only $5 \%$ market share [6].

The industry has witnessed a steady growth over the decades. In addition to its contribution to the GDP and employment generation, the industry plays a key role in the implementation of the public health policy of the government. The industry is able to attract steady inflows of Foreign Direct Investments and also collaborations with MNCs for development of new drugs. Producing quality drugs at competitively low prices is one of the biggest advantages of the industry. The industry works within a regulatory framework, where many aspects of its functioning, such as manufacturing, fixing of prices, advertising of its products and sales promotion are regulated. In the pandemic era, the industry has scaled up and has achieved success in the manufacture and supply of the Covid vaccine, in spite of the various glitches.

\section{REVIEW OF RELATED WORKS :}

Various studies have been carried out to analyse the Indian pharma sector in terms of its growth and reasons for its low-cost advantage. There have been studies analysing the financial performance and impact of mergers on performance metrics. Vishwanathan et al. [7] studied the growth as well as the contribution of the pharma sector to the Indian economy. According to the authors, price controls prevailing at the time of study, was one of the major factors hindering the growth of the sector. The study maintains that the inherent low-cost advantage enjoyed by Indian firms has enabled them to challenge the firms manufacturing generic drugs in the US. Ravikiran et al. [8] studied the performance of the pharma sector in terms of sales, net profits, amount invested on R\&D, patents granted, ANDA and DMF filings and approvals with USFDA in the aftermath of TRIPS, for ten years. The study ranks leading pharma companies in terms of these performance metrics. The study observes that the period between 1995 and 2008 has been a productive one, with the industry becoming a net foreign exchange earner. Akhtar [9] traces the historical growth of the Indian Pharmaceutical sector, the trends in the production of bulk drugs and formulations, the extent of investment in R\&D by major pharma companies, employment opportunities created by the sector, new initiatives of the sector such as contract research and manufacturing services and new clinical trial entities. The study concludes that adherence to international quality standards in manufacturing is a source of a huge advantage to the sector. Venkateswarulu [10] studied the mergers and acquisitions that have taken place in the pharma sector. The study outlines the various laws that regulate the M\& As in India. The study evaluates the impact of the mergers on the merged entities and compares the same to that of pharma companies in several European countries. The study concludes that around half the mergers and acquisitions are not successful. Puwar et al. [11] carried out Dupont Analysis on 12 leading pharma companies for a period of five years from 2007-08 to 2016-17. The study found that of the 12 companies analysed, Torrent Pharmaceuticals is the most profitable for its shareholders, while Sun Pharma is the least profitable on the basis of Return on Equity. Saravanan and Prabhu [12] analysed the profitability position of three pharma companies for a period of 5 years from 2009-10 to 2013-14 with a view to identify the variables 
which influence profitability. The study suggests that by managing cost of production, investment in fixed assets and sales turnover, profitability could be improved.

Table 1: Review of related works on ABCD Analysis

\begin{tabular}{|c|c|c|c|}
\hline Sl. No. & Industry/ Concept studied & Findings & References \\
\hline 1 & Black Ocean Strategy & $\begin{array}{l}\text { Factors supporting advantages } \\
\text { and benefits are more effective } \\
\text { compared to constraints and } \\
\text { disadvantages of the system. }\end{array}$ & Aithal, et al. (2015) [13] \\
\hline 2 & Higher Education Stage Model & $\begin{array}{l}\text { Student progression } \quad \text { and } \\
\text { development could be enhanced } \\
\text { through } \quad \text { stage } \quad \text { model } \\
\text { intervention. }\end{array}$ & Aithal, et al. (2016) [14] \\
\hline 3 & $\begin{array}{lll}\text { Online Campus Placement } \\
\text { Model }\end{array}$ & $\begin{array}{l}\text { Identified } 158 \text { crucial elements } \\
\text { through which the } 4 \text { constructs of } \\
\text { the study are determined. }\end{array}$ & Shenoy \& Aithal (2016) [15] \\
\hline 4 & $\begin{array}{l}\text { 'Theory A' on Organizational } \\
\text { Performance }\end{array}$ & $\begin{array}{l}\text { Analysed the Theory A as a tool } \\
\text { for Organizational Performance } \\
\text { using ABCD framework and } \\
\text { identifies the factors that affect } \\
\text { the determinant issues of Theory } \\
\text { A for every key issue. }\end{array}$ & Aithal \& Kumar (2016) [16] \\
\hline 5 & Six Thinking Hats Technique & $\begin{array}{l}\text { Analysed the Six Thinking Hats } \\
\text { Technique as a tool for } \\
\text { Organizational decision making } \\
\text { and problem solving. The paper } \\
\text { carries out a factor and elemental } \\
\text { analysis by identifying the } \\
\text { Advantages, Benefits, } \\
\text { Constraints and Disadvantages } \\
\text { by a detailed identification of } \\
\text { determinant issues and key } \\
\text { issues. }\end{array}$ & Aithal, et al. (2016) [17] \\
\hline 6 & $\begin{array}{l}\text { Generating Returns from } \\
\text { Bottom of the Pyramid (BoP) }\end{array}$ & $\begin{array}{l}\text { Studied the effectiveness of } \\
\text { generating profits at the BoP } \\
\text { using ABCD Framework. }\end{array}$ & Raj \& Aithal (2018) [18] \\
\hline
\end{tabular}

\subsection{Research Gap}

The previous studies on ABCD analysis have identified the various constituent elements which can be used to carry out analysis of various industries/organizations/business models. Although there have been some studies that have analysed the reasons for low-cost competitive advantage enjoyed by the pharma sector in the global market, there have been no studies that have highlighted the mutual impact of functioning of the pharma industry on the environment, using the ABCD Framework.

\subsection{Research Agenda}

The present paper identifies the critical elements within the macro-environment which have become the Advantages, Benefits, Constraints and Disadvantages of the pharma industry.

\section{OBJECTIVES OF THE STUDY :}

(1) To understand the Advantages enjoyed by the Indian Pharma sector.

(2) To study the Indian Pharmaceutical sector in the light of various Benefits it offers to diverse groups of stakeholders.

(3) To study the Constraints which restrict the working of the Pharma sector.

(4) To enumerate the Disadvantages arising out of Pharma manufacturing. 


\section{RESEARCH DESIGN :}

\subsection{Methodology of Data Collection:}

The data for the study has been collected from secondary sources. The data is collected from published reports on the pharmaceutical industry such as IBEF report on Indian Pharma Sector, Haitong report on Indian Pharmaceuticals, Jefferies Equity Research Report on Indian Pharmaceuticals, Pharmaceutical's sector report by Equirus and Report on Current Status of Pharma APIs from India's Perspective.

\subsection{Research Tools:}

The main tool used to Study the Indian Pharmaceutical Sector is the Advantages, Benefits, Constraints and Disadvantages (ABCD) framework. The other tools of industry analysis used in the paper to identify the four constructs of ABCD model for the Pharma industry include, Porter's Five Forces theory to study the competition in the industry, PESTLE analysis to study forces within the macro-environment, Herfindhal-Hirshman Index (HHI) to study the concentration in the industry and SWOT analysis. The $\mathrm{ABCD}$ analysis is a better tool of Industry analysis as it enables industry members to know the macroeconomic factors that can support or hinder their functioning and at the same time, the stakeholders can study the gains and adverse repercussions of the industry's functioning.

\section{ABCD ANALYSIS OF INDIAN PHARMACEUTICAL INDUSTRY :}

The ADCD analysis when applied to the Indian Pharmaceutical Industry reveals the following advantages, benefits, constraints and disadvantages arising out of the operations of the industry.

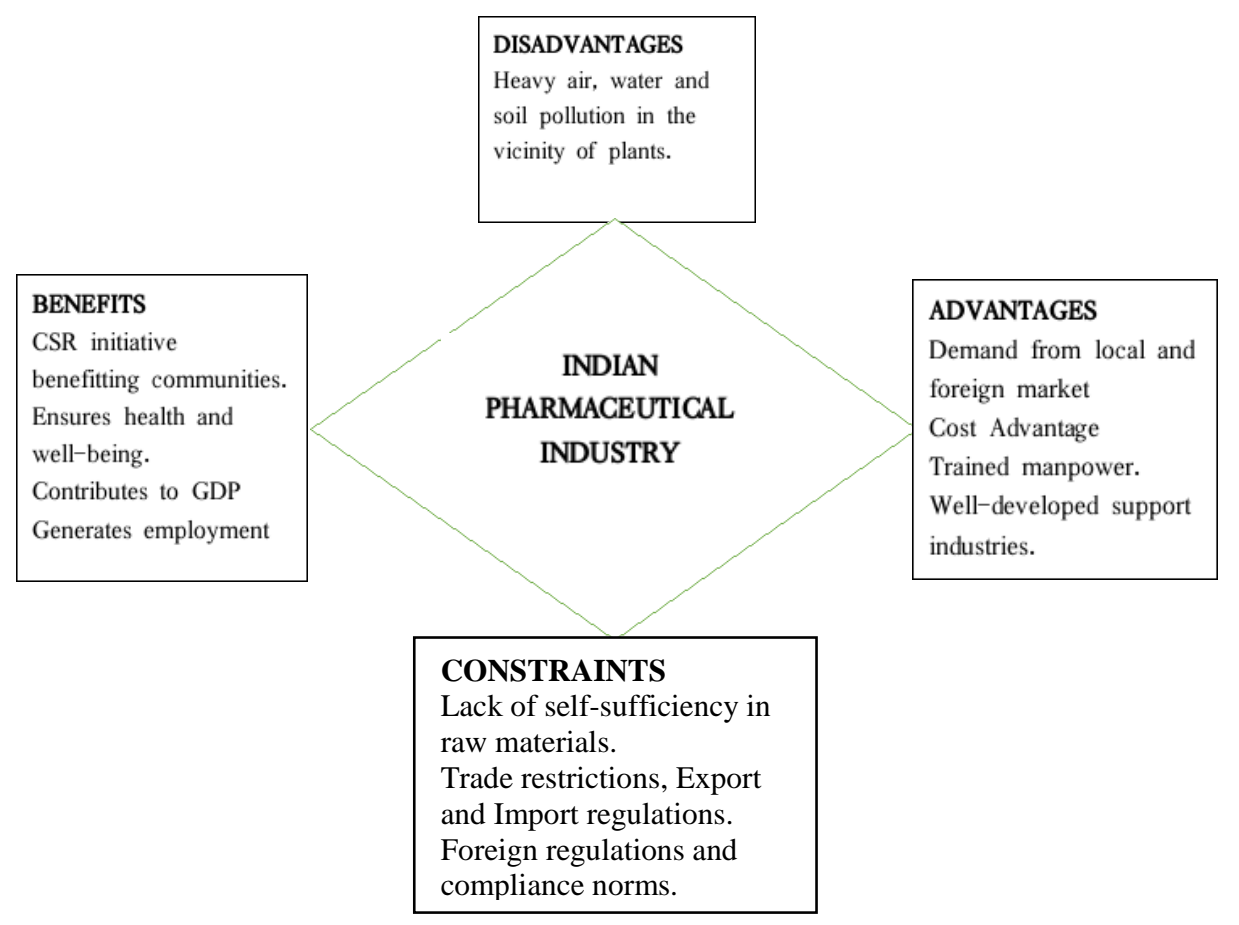

Fig. 1: ABCD Framework of Indian Pharmaceutical Sector

\subsection{Advantages:}

\subsubsection{Advantages resulting from Political factors:}

The Indian Pharma industry has received an impetus as a result of several policy decisions of the Govt. The increased budgetary allocation for health care (Rs. 2,23,846 crore in FY 2021-22, compared to Rs. 94,452 crore in FY 2020-21) [19], the Ayushman Bharath Pradhan Mantri Jan Arogya Yojana whose main target is to make free health care available to around 50 crore people [20], the establishment of the Jan Aushadi Kendras which sell generic medicines at lower prices than their branded drugs, have all increased the demand for the pharma products. 
In pursuance of its policy towards achieving greater self-reliance or Atmanirbhar Bharath, the govt proposes to set up three bulk drug parks in the country to make chemical compounds or APIs. This will help to reduce the industry's reliance on imports, particularly from China, for raw material requirements.

5.1.2. Advantages arising from Economic factors:

The factors within the economic environment of the country which have contributed to the growth of the pharma sector are

(1) FDI Inflows: A steady inflow of Foreign Direct Investment has spurred the growth of the pharma industry. The Government permits 100\% FDI in greenfield pharma ventures and 74\% in brownfield ventures, encouraging more players to enter the industry. Table 2 shows the inflow of FDI to the industry for a 5 -year period.

Table 2: Total FDI into the Indian Pharma Sector 2014-15 To 2019-20

\begin{tabular}{|l|l|}
\hline YEAR & AMOUNT (Rs.) (In crore) \\
\hline $2014-15$ & 9,052 \\
\hline $2015-16$ & 4,975 \\
\hline $2016-17$ & 5,723 \\
\hline $2017-18$ & 6,502 \\
\hline $2018-19$ & 1,842 \\
\hline $2019-20$ (up to September) & 2,065 \\
\hline
\end{tabular}

Source: The Healthworld, Economic Times [21].

(2) M\&A: The Indian Pharma sector has witnessed a large number of domestic as well as cross- border mergers and acquisitions. These have helped pharma companies to widen their product lines, access to more manufacturing plants with FDA approval, improve their distribution channels and widen their customer base and improve market share.

(3) Low cost of manufacturing: The relatively lower cost of labour in India has enabled pharma companies to keep their overall manufacturing costs low compared to the international markets. It is estimated that when compared to developed countries, cost of setting up an FDA inspected plant is 50\% less, operation and production costs are around $40-70 \%$ less and labour costs are approximately $60-70 \%$ lesser in India [22].

\subsubsection{Advantages derived from Socio- Cultural environment:}

The socio-cultural factors that have contributed to the growth of the pharma industry can be summarised as under:

(1) Demographic factors - The country's population includes a sizable section of older people who consequently require health care facilities. As much as $6.57 \%$ of the country's population is over the age of 65 years [23].

(2) Lifestyle factors - the prevailing lifestyle among the people has promoted a greater degree of health consciousness. This has resulted in the increasing utilisation of healthcare facilities. One more consequence of the current lifestyle is the greater incidence of the so-called lifestyle diseases among a larger section of the population including younger people. These factors have led to an increased consumption of pharma products.

(3) Education - The socio- cultural environment of the country with its emphasis on education as a means to achieve personal and professional growth has created a vast pool of trained work force. The number of seats across India for pharmacy courses increased to 2,62,698 in 2019-20 from 2,04,951 in 2018-19. The number of pharmaceutical institutes rose to 3276 in 2019-20 from 2306 in 2018-19 [24].

\subsubsection{Advantages from Legal environment:}


The regulatory environment is supportive to the industry. A study [25] finds that market authorization typically takes around 12 months after submission of documents and that the submission costs are one of the lowest.

\subsubsection{Advantages from Global environment:}

There is a huge demand for Indian generic drugs and vaccines in the global market. The off patenting of drugs creates a big opportunity to the industry. $\$ 55 \mathrm{bn}$. worth drugs became off-patent during the period 2017-19 [26].

\subsubsection{Advantages arising out of support industries:}

The upstream partners of the pharma industry can be categorised into Materials Providers, Equipment manufacturers and Service providers. Material suppliers include makers of Key Starting Materials, Excipients i.e., the chemical industry and Packing Materials.

(1) Chemical Industry: The raw materials for the pharma industry are products from the chemical industry. Pharmaceutical industry is one of the largest consumers of the chemical industry. There are around 350 bulk medicines, in other words, chemicals that are used in drug production. The Indian chemical industry is a highly fragmented industry with a large number of producers.

(2) Packaging industry: Packaging is crucial in preserving the quality of the drug. Various types of packaging used in the pharma industry include containers, aluminium foil, injectables, vials, bottles, cartons, paperboard, lamitubes, etc. A well-developed packaging industry is an advantage of the pharma sector. The packaging industry includes both domestic and foreign players. MNCs like Amcor, Huhtamaki and West Pharma are the leading firms, whereas U Flex and Essel Propack are the leading players in the pharma packaging industry.

(3) Equipment Manufacturers: Equipment manufacturing industry has categories such as instrumentation and lab. equipment, pharma $\mathrm{R} \& \mathrm{D}$ tools and equipment, packaging equipment. There are a large number of plants engaged in pharma machine manufacturing.

(4) IT/ITES: A well-developed IT and ITES sector has provided able support services to the sector.

(5) Research \& Development (R\&D): In the area of R\&D, the country has several advantages. Among these is the availability of a large pool of scientific personnel. The country also has a strong base in contract research. According to a report published by Market Research Future [MRFR], "The Indian CRO market is expected to reach a market valuation of USD 986.9 million, growing at $12 \%$ CAGR during the period of 2017-23" [27].

5.2. Benefits:

5.2.1. Benefits to the Society:

Corporate Social Responsibility (CSR) activities of the various players in the industry have immensely benefited the society at large, particularly the communities living near the pharma plants. A list of CSR activities of select pharma companies is shown in table 3 below :

Table 3: CSR Activities of Selected Pharma Companies

\begin{tabular}{|c|c|c|c|}
\hline $\begin{array}{l}\text { NAME OF THE } \\
\text { COMPANY }\end{array}$ & $\begin{array}{l}\text { AGENCIES PROMOTED } \\
\text { FOR CSR }\end{array}$ & $\begin{array}{l}\text { BROAD AREAS FOR } \\
\text { CSR }\end{array}$ & $\begin{array}{l}\text { AMOUNT } \\
\text { SPENT ON } \\
\text { CSR in (2019- } \\
20)\end{array}$ \\
\hline Sun Pharmaceuticals & $\begin{array}{l}\text { Foundation for Disease } \\
\text { Elimination and Control of } \\
\text { India, Sun Pharma Science } \\
\text { Foundation, Sun Pharma } \\
\text { Community } \\
\text { Society. }\end{array}$ & $\begin{array}{l}\text { It has developed Model } \\
\text { schools to provide } \\
\text { quality education to } \\
\text { rural students and } \\
\text { Mobile Healthcare } \\
\text { Units to serve over } \\
650000 \text { people. }\end{array}$ & Rs. 4.37 Crore \\
\hline
\end{tabular}




\begin{tabular}{|l|l|l|l|}
\hline Cipla ltd. & $\begin{array}{l}\text { Cipla Cancer \& Aids } \\
\text { Foundation, Cipla Foundation, } \\
\text { National Health Mission, } \\
\text { Chest Research Foundation, } \\
\text { Skill Development and } \\
\text { Rehabilitation Centre among } \\
\text { others. }\end{array}$ & $\begin{array}{l}\text { Economic and Social } \\
\text { Infrastructure Rural } \\
\text { Development }\end{array}$ & Rs. 36.31 crore \\
\hline Lupin & $\begin{array}{l}\text { Lupin Human Welfare and } \\
\text { Research Foundation }\end{array}$ & $\begin{array}{l}\text { Rural Infrastructure } \\
\text { Development, Natural } \\
\text { Resource Management, } \\
\text { Disaster Relief and } \\
\text { Mitigation, Learn and } \\
\text { Earn Programme }\end{array}$ & Rs.20 Crores \\
\hline Dr Reddy's Laboratories & $\begin{array}{l}\text { Dr. Reddy's Foundation and } \\
\text { other implementing partners }\end{array}$ & $\begin{array}{l}\text { Education, Livelihood, } \\
\text { Health, Water and } \\
\text { Sanitation, } \\
\text { Environmental } \\
\text { Sustainability. }\end{array}$ & Rs. 27.53crs. \\
\hline Cadila Healthcare & $\begin{array}{l}\text { Zydus Foundation and other } \\
\text { implementing partners. }\end{array}$ & $\begin{array}{l}\text { Preventive Healthcare, } \\
\text { Water and Sanitation, } \\
\text { Employment, } \\
\text { Education, Livelihood } \\
\text { enhancement. }\end{array}$ & Rs. 22.01 Crs. \\
\hline Aurobindo Pharma & $\begin{array}{l}\text { Aurobindo Pharma } \\
\text { Foundation }\end{array}$ & $\begin{array}{l}\text { Safe Drinking Water, } \\
\text { Environmental } \\
\text { Sustainability, } \\
\text { Ecological Balance and } \\
\text { Conservation of Natural } \\
\text { Resources, Old Age } \\
\text { homes, Rural Sports. }\end{array}$ & Rs. 48.60crs. \\
\hline
\end{tabular}

Source: Compiled from indiacsr.in [28]

In the COVID-19 pandemic era, the industry's biggest success has been making available the vaccine, not only to the domestic market but also to other countries.

Under the Vaccine Maitri Scheme, India has given 66.3 million vaccine doses to 95 countries [29].

\subsubsection{Benefits to the Economy:}

The pharma sector contributes around $1.72 \%$ to the country's GDP. The sector creates 2.7 million jobs directly and indirectly. It is one of the top 5 sectors that reduce trade deficit with an annual trade surplus of USD 11 billion. Also, the sector has reached USD 24.44 billion in FY21 [30].

\subsubsection{Public Health Benefits:}

The industry has immensely contributed to public health through innovations in life saving medicines, disease prevention through vaccination etc. With the collaboration of the other agencies involved, Indian Pharma sector has helped in achieving public health outcomes such as $36 \%$ lower per person disease burden and $100 \%$ eradication of polio. The sector has succeeded in lowering the cost of lifethreatening diseases such as Leukaemia and Hepatitis C, to around 5\% of the original cost [31].

\subsection{Constraints:}

\subsubsection{High degree of regulations:}

The Government regulates the working of the pharma industry. The National Pharmaceutical Pricing Authority (NPPA) was established in 1997 to implement and enforce the provision of the Drugs Price Control Order. The Authority also monitors the availability of drugs to deal with any shortages. The pharma prices should be as per the Drugs Price Control Order. The Central Drugs Standard Control 
Organisation (CDSCO) is the regulatory body for pharmaceuticals and medical devices. Its functions include inspections during the pre and post licencing stage of setting up pharma units, market surveillance and drug recall, where the situation calls for recall.

\subsubsection{High entry barriers:}

The pharmaceutical industry is a capital-intensive industry involving huge outlays for $R \& D$, the latest technology and equipment. Moreover, operational costs involved are also high. Starting a pharma unit requires multiple licencing. The provisions of Indian Patent Act make it difficult to imitate the competitor's product. All these factors contribute to the high entry barriers in the pharma sector.

\subsubsection{Challenges in marketing:}

The consumers of the pharma industry can be classified into bulk buyers and individual buyers. In the case of the individual buyers, buying pattern differs in the case of OTC and prescribed drugs. For prescription drugs, the buying decisions are entirely influenced by the prescribing physicians. This means that expert opinion of these professionals' influences buying behaviour. The pharma companies have to appoint medical representatives to promote and sell their products, usually by personally visiting doctors and hospitals. In the case of OTC drugs, the pharma companies use various advertising media to reach out to the consumers directly.

As bulk buyers, hospitals also have a lot of bargaining power.

\subsubsection{Dependence on imports for raw materials:}

One major weakness that the Indian pharma sector has to overcome is the dependency on other countries, mainly China for the import of chief raw materials in the manufacture of Active Pharmaceutical Ingredients (APIs) and Drug Intermediaries (DIs).

\subsubsection{Intense competition:}

Indian Pharma industry is highly fragmented. Table 4 shows the market concentration in the industry using the Herfindahl Hirschman Index (HHI). An index lower than 1500 indicates low market concentration [32].

Table 4: Herfindahl Hirschman Index (HHI) of Indian Pharma Industry (2020)

\begin{tabular}{|l|c|c|}
\hline Company & Market Share (\%) & MS $^{2}$ \\
\hline Sun Pharmaceuticals & 8 & 64 \\
\hline Abbott & 5 & 25 \\
\hline Cipla & 5 & 16 \\
\hline Lupin & 4 & 16 \\
\hline Cadila Healthcare & 4 & 16 \\
\hline Mankind Pharma & 4 & 9 \\
\hline Torrent Pharma & 3 & 9 \\
\hline Alkem & 3 & 9 \\
\hline GSK & 3 & 9 \\
\hline
\end{tabular}




\begin{tabular}{|l|l|l|}
\hline Intas & 3 & \multicolumn{1}{|c|}{9} \\
\hline & & $\sum \mathrm{MS}^{2}=198$ \\
\hline
\end{tabular}

Source: Equirus [33], Author's Calculation

The HH index of the pharma industry for the year 2020 is 198 which shows that a high degree of competition prevails in the industry.

\subsection{Disadvantages:}

The pharma industry though involved in production of drugs essential for health and wellbeing, has a great deal of adverse impact on the environment and communities of the regions where its plants are located. The industry is one of the biggest polluters. The Indian Environment Ministry classifies pharmaceutical manufacturing as a "Red Category Activity" because of the hazardous waste it produces. For example, the Hyderabad region, a major hub of bulk drug production has been severely affected by the effluents discharged by the pharma units. A study in 2016 found that water of 23 out of 25 water bodies are unfit, not only for drinking and domestic use, but also for irrigation and industrial cooling. The Musi River is the 6th most polluted river of the country. Scientists have found dangerous multi-drug resistant pathogens in the water bodies [34].

Successive studies [35- 37] have shown that air, water and soil in Telangana are significantly contaminated by toxic chemicals and heavy metals such as copper, lead, mercury and arsenic.

Another disadvantage is the problem of substandard drugs that could have adverse impact on the health of the consumers. Domestically produced generic drugs have often failed quality tests [38].

\section{FINDINGS :}

(1) The ability to manufacture low-cost quality drugs is the biggest advantage for the Indian Pharma Sector.

(2) Efforts by the Government of India to open up healthcare access to a large section of population has proved to be a growth-driver for the industry.

(3) In the COVID-19 pandemic era, the industry's success has been making available the vaccine, not only to the domestic market but also to other countries.

(4) The Herfindahl Hirschman index of the industry is 198, indicating low market concentration.

(5) The off-patenting of drugs has created a huge opportunity for the industry members to encash.

(6) The operations of the industry, though beneficial to the health and well-being of the populace, have an adverse impact on the ecology.

(7) Categorised as a red category activity, the industry's operations cause air, water and soil pollution.

\section{RECOMMENDATIONS :}

(1) The pharmaceutical industry has a long way to go in greening its operations. Green chemistry, which involves designing of products and processes in such a way that it reduces or eliminates generation of harmful chemical substances and other pollution control measures are a key to achieving environmental sustainability.

(2) The Indian pharma industry is on the threshold of a major technological change. An early adoption of these technologies would result in increased competitiveness of the industry in the global market.

\section{CONCLUSION :}

The Indian Pharmaceutical Industry is known for its low cost, quality generic drugs. In the wake of the COVID pandemic, the industry has lived up to this image and has made available not only the COVID vaccine but necessary drugs required in large quantities to combat the pandemic, both in the domestic as well as the global markets. The changing global political and economic scenario offers a large scope for the industry to expand its global market share. Sweeping changes in technology such as, AR and VR in pharma manufacturing, silico trials or organs- on- chips in conducting clinical trials, AI and 
Machine Learning in studying the effects of drugs on humans, and e commerce in marketing of pharma products, are set to revolutionise pharma value chain activities. The government has undertaken various measures to overcome the chief constraint of the industry i.e., reliance on raw material imports. The pharma industry enjoys a lot of advantages which it can leverage to improve its global presence.

\section{REFERENCES :}

[1] Porter, M. E. (2008). The five competitive forces that shape strategy. Harvard Business Review, 86(1), 78 .

Google Scholar $x^{7}$

[2] Aithal, P. S. (2017). ABCD Analysis as Research Methodology in Company Case Studies. International Journal of Management, Technology, and Social Sciences (IJMTS), 2(2), 40-54.

Google Scholar $X^{\top} \quad$ CrossRef/DOI $x^{\top}$

[3] Zion Market Research, (2021, July 05). Generic Drugs Market - Global Industry Analysis. Zion Market Research, Retrieved from Generic Drugs Market by Brand (Pure generic drugs, Branded generic drugs) By Application (Central nervous system (CNS), Cardiovascular, Dermatology, Oncology, Respiratory, and Others): Global Industry Perspective, Comprehensive Analysis and Forecast, 2020 - 2028 (zionmarketresearch.com) Accessed on 04/11/2021.

[4] Singh, R. (2021, August 12). Post COVID: Pharmaceutical Industry has become Alluring Career Option. India Infoline News Service, Retrieved from Post COVID: Pharmaceutical Industry has become Alluring Career Option (indiainfoline.com) Accessed on 01/11/2021.

[5] IBEF, (2021, August). Indian Pharmaceuticals Industry Report. Indian Brand Equity Foundation, Retrieved from Pharma Industry in India: Pharma Sector Overview, Market Size, Analysis... IBEF Accessed on 01/11/2021.

[6] Groww, (2021, August 17). An Overview of the Pharma Industry in India. groww.in, Retrieved from The Pharma Industry in India: An Overview on its Growth (groww.in) Accessed on 01/11/2021.

[7] Viswanathan, H. (2002). India's Pharmaceutical Industry: A Growing Influential Force in the World Pharmaceutical Market. Journal of Managed Care Pharmacy, 8(3), 211-215.

\section{Google Scholar X CrossRef/DOIX}

[8] Kiran, R., \& Mishra, S. (2009). Performance of the Indian pharmaceutical industry in post-TRIPS period: a firm level analysis. International Review of Business Research Papers, 5(6), 148-160. Google Scholar X

[9] Akhtar, G. (2013). Indian pharmaceutical industry: an overview. IOSR journal of Humanities and Social Science, 13(3), 51-66.

Google Scholar $\chi^{\lambda}$

\section{CrossRef/DOI X}

[10] Venkateswarlu, K. (2018). Mergers and Acquisitions: Boom in the Indian Pharma Industry. UPI Journal of Business Management and Computer Applications, 1(1), 26-30. Google Scholar X

[11] Puwar, A. et al (2018), Financial Analysis of Pharmaceutical Companies in India. International Journal of Science and Research (IJSR), 7(8), 418 - 426.

Google Scholar X

[12] Saravanan, S., \& Prabhu, R. (2018). A Study on Financial Performance of Pharmaceutical Company. International Journal of Trend in Scientific Research and Development 2(3), 19041907.

Google Scholar X

CrossRef/DOIX

[13] Aithal, P. S., Shailashree, V., \& Kumar, P. M. (2015). Application of ABCD Analysis Model for Black Ocean Strategy. International Journal of Applied Research, 1(10), 331-337.

Google Scholar X 
[14] Aithal, P. S., Shailashree, V., \& Kumar, P. M. (2016). ABCD analysis of Stage Model in Higher Education. International Journal of Management, IT and Engineering, 6(1), 11-24.

Google Scholar \}

[15] Shenoy, V., \& Aithal, P. S. (2016). ABCD Analysis of On-line Campus Placement Model. IRAInternational Journal of Management \& Social Sciences, 5(2), 227-244.

Google Scholar X

[16] Aithal, P. S., \& Kumar, P. M. (2016). CCE Approach through ABCD Analysis of 'Theory A'on Organizational Performance. International Journal of Current Research and Modern Education (IJCRME), 1(2), 169-185.

Google Scholar $X^{\top}$

[17] Aithal, P. S., Kumar, P. M., \& Shailashree, V. (2016). Factors \& elemental analysis of six thinking hats technique using ABCD framework. International Journal of Advanced Trends in Engineering and Technology (IJATET), 2456-4664.

Google Scholar X

[18] Raj, K., \& Aithal, P. S. (2018). Generating Wealth at the Base of the Pyramid-a Study Using ABCD Analysis Technique. International Journal of Computational Research and Development (IJCRD), 3(1), 68-76.

Google Scholar $X^{\top}$

[19] PTI (2021, February 02). Higher Budget allocation for healthcare a welcome move for the sector, says Industry. Economic Times, Retrieved from Higher Budget allocation for healthcare a welcome move for the sector, says Industry - The Economic Times (indiatimes.com) Accessed on $04 / 11 / 2021$

[20] Sharma, A., \& Aggarwal, A. K. (2020). The Role of Pradhan Mantri Jan Arogya Yojana in Managing COVID-19 in India. International Journal of Health Systems and Implementation Research, 4(2), 17-23.

Google Scholar $X^{7}$

[21] Healthworld (2020, February 08). FDI in drugs \& pharma sector rose to Rs 2,065 cr in April-Sept FY20: Govt. Economic Times, Retrieved from https://health.economictimes.indiatimes.com/news/pharma/fdi-in-drugs-pharma-sector-rose-tors-2065-cr-in-april-sept-fy20-govt/74021198 Accessed on 09/01/2022.

[22] WP Brand Studio (2021, February 08). India's low pharma costs are good for drug companies, good for consumers. The Washington Post, Retrieved from Indias low pharma costs are good for drug companies, good for consumers (washingtonpost.com) Accessed on 07/11/2021.

[23] Statistics Times, (2021, October 30). Population of India. Statistics Times, Retrieved from India population 2021 - StatisticsTimes.com Accessed on 05/11/2021.

[24] Bhandary, S. (2019, May 19). Pharmacy seats across India up by nearly $30 \%$ in a yr. Hindustan Times, Retrieved from Pharmacy seats across India up by nearly $30 \%$ in a yr $\mid$ Latest News India - Hindustan Times Accessed on 01/11/2021.

[25] Sutar, M., Gawhane, D., \& Tenpe, C. R. (2013). Study of Drug Regulatory Approval Process an Comparative Requirement of Common Technical Documents (CTD) in Europe, USA and India in Coordination with Drug Developmental Process. International Journal of Pharmaceutical Sciences Review and Research, 20(2), 68-79.

Google Scholar X

[26] Cyrill, M. (2021, April 13). India's Pharmaceutical Industry - Foreign Investment Opportunities, Incentives. India Briefing, Retrieved from India's Pharmaceutical Industry - Investment Opportunities, Incentives (india-briefing.com) Accessed on 05/11/2021.

[27] Market Research Future, (2019, November 12). Contract Research Organization India Market 2019 Demands with Size, Share Analysis and Industry Revenue up to 2023. Market Research Future, 
Retrieved from Contract Research Organization India Market 2019 Demands with Size, Share Analysis and Industry Revenue up to 2023 | Medgadget Accessed on 04/11/2021.

[28] India CSR Network (2021). CSR. indiacsr.in, Retrieved from CSR Archives - India CSR Network Accessed on 09/01/2022.

[29] Outlook web desk, (2021, October 22). 100 Crore Shots: How India Achieved Covid-19 Vaccination Milestone In 280 Days, Outlook, Retrieved from 100 Crore Shots: How India Achieved Covid-19 Vaccination Milestone In 280 Days (outlookindia.com) Accessed on $05 / 11 / 2021$

[30] Indian Pharmaceutical Alliance (2019, June). The Indian pharmaceutical industry - the way forward. Indian Pharmaceutical Alliance, Retrieved from The Indian pharmaceutical alliance position papers (ipa-india.org) Accessed on 01/11/2021.

[31] Indian Pharmaceutical Alliance (2019, June). The Indian pharmaceutical industry - the way forward. Indian Pharmaceutical Alliance. Retrieved from The Indian pharmaceutical alliance position papers (ipa-india.org) Accessed on 01/11/2021.

[32] Hayes, A. (2021, August 30). Herfindahl-Hirschman Index (HHI), Investopedia, Retrieved from Herfindahl-Hirschman Index (HHI) Definition (investopedia.com) Accessed on 05/11/2021.

[33] Equirus (2020, December 20). Pharmaceuticals Sector Report, Equirus, Retrieved from Research Reports - Equirus Accessed on 09/01/2022.

[34] Technology Networks, (2018, January 29). Pharmaceutical Manufacturing Pollution Threatens Hyderabad. Technology Networks, Retrieved from Pharmaceutical Manufacturing Pollution Threatens Hyderabad | Technology Networks Accessed on 01/11/2021.

[35] Fick, J., Söderström, H., Lindberg, R. H., Phan, C., Tysklind, M., \& Larsson, D. J. (2009). Contamination of surface, ground, and drinking water from pharmaceutical production. Environmental Toxicology and Chemistry, 28(12), 2522-2527.

Google Scholar $x^{\top} \quad$ CrossRef/DOI $x^{\top}$

[36] Machender, G., Dhakate, R., Rao, S. M., Rao, B. M., \& Prasanna, L. (2014). Heavy metal contamination in sediments of Balanagar industrial area, Hyderabad, Andhra Pradesh, India. Arabian Journal of Geosciences, 7(2), 513-525.

Google Scholar $X^{\top}$

[37] Mathew, G., \& Unnikrishnan, M. K. (2012). The emerging environmental burden from pharmaceuticals. Economic and Political Weekly, 47(18), 31-34.

Google Scholar X

[38] Singh, G. (2020, August 8). The menace of counterfeit drugs that India must fight. Livemint, Retrieved from Opinion | The menace of counterfeit drugs that India must fight (livemint.com) Accessed on 19/10/2021. 